DOI: $\underline{10.20472 / E S .2015 .4 .1 .005}$

\title{
TOWARDS A MORE EFFECTIVE POVERTY REDUCTION IN MEXICO: A GENERAL EQUILIBRIUM ASSESSMENT
}

\section{JOSÉ LUIS VIVEROS AÑORVE}

\begin{abstract}
:
Oportunidades, Mexico's conditional cash transfer program, has proved to be an insufficient tool for poverty alleviation in a phase of low and uneven economic growth, and it has failed to achieve its intended goal to break the intergenerational transmission of poverty. In this context, what strategy would lead to a more effective poverty reduction without jeopardizing Mexico's economic development? This study carries out a general-equilibrium assessment in a bottom-up approach in the regional setting of Chiapas, the poorest state in Mexico. It finds that a policy set composed of a 20 per cent, 10 per cent, and 5 per cent increase in fixed investment in agriculture, construction, and manufacturing, respectively, as well as distributional changes in Oportunidades and other social transfers, pro-poor direct tax rate changes, a higher value-added tax rate and the elimination of labor and payroll taxes, may notably boost real GDP growth by 6 per cent. This economic strategy may also reduce informal employment, may ensure that formal labor income growth increases more than capital income, and may generate pro-poor growth, enhancing a process of structural transformation and rural change. Moreover, poverty would fall. The growth elasticity of poverty shows that for every one-percentage increase in GDP, poverty would decline by 2.95 per cent on average.
\end{abstract}

\section{Keywords:}

Oportunidades, conditional cash transfers, poverty reduction, pro-poor growth, rural change, structural transformation, Chiapas, Mexico

JEL Classification: E16, 132, 011

\section{Authors:}

JOSÉ LUIS VIVEROS AÑORVE, University of Bonn, Germany, Email: joseluis.viveros@uni-bonn.de

\section{Citation:}

JOSÉ LUIS VIVEROS AÑORVE (2015). Towards a more effective poverty reduction in Mexico: a general equilibrium assessment. International Journal of Economic Sciences, Vol. IV(1), pp. 75-107., 10.20472/ES.2015.4.1.005

Acknowledgment: The author is grateful to the constructive comments of two anonymous referees. He would also like to thank the German Academic Exchange Services (DAAD), the fiat panis Foundation, and the Center for Development Research (ZEF) for their financial support. 


\section{Introduction}

Despite the fact that Mexico has achieved macroeconomic stability after the financial crisis in 1995, economic growth has been low and uneven over the course of the last decades. In the period 1994-2014, real Gross Domestic Product (GDP) per capita grew on average by $0.8 \%$. In this context, poverty remains high. Nationwide, 45.5 per cent of the population is multi-dimensionally poor and 51.6 per cent has an income below the wellbeing line while at regional level, in Chiapas, the poorest state, more than 70 per cent of inhabitants are poor (CONEVAL, 2013).

Conditional cash transfers (CCTs), better known as the Oportunidades program, recently relaunched as Prospera under the administration of President Peña Nieto, have been the main tool for poverty reduction since mid-90s. Oportunidades is a pioneering social program aimed at enhancing the human capital of the poor to break the intergenerational transmission of poverty by transferring cash conditioned to children and youth's school enrollment and their regular attendance, regular health check-ups of all household beneficiaries, and regular attendance to talks on nutrition and health care to improve the overall situation of households in extreme poverty on three areas, health, nutrition, and education (Levy \& Rodríguez, 2005). At the time of its implementation, it was executed as a Randomized Control Trial (RCT) for evaluation purposes ${ }^{1}$ (Behrman \& Todd, 1999), becoming the first large-scale social program in an upper-middle income country setting to apply an $\mathrm{RCT}^{2}$. Oportunidades has been extensively reviewed and evaluated, specifically to assess its short- and mid-term impacts on educational attainment, nutrition, mortality and fertility rates, and overall health of beneficiaries. The following literature review ${ }^{3}$ is focused only on recent studies about the program's occupational and wage effects, long-term impact on schooling and poverty reduction, labor market outcomes, and type I (exclusion) and type II (inclusion) errors.

To identify the expected direct and indirect effects of conditional cash transfers on children's allocation of time, and the expected effects on poverty and income distribution, Debowicz and Golan (2013) build an applied econometric-based microsimulation model combined with a macro Computable General Equilibrium (CGE) model (a top-down/bottom-up approach). With this combined model, the authors capture two transmission channels: a) occupational effect; and, b) wages effect. The first channel allows assessment of how changes in the program's coverage, in its design and in child wages, may lead to children's reallocation of time between work and school. The second channel assesses how changes in the child labor supply may lead to a new average general equilibrium real wage in the child labor market which affects the total disposable household income. They find that Oportunidades improves

\footnotetext{
${ }^{1}$ RCTs are a type of scientific experiment to test the impact of interventions in a randomly selected subpopulation. For a practical guide about how to conduct social experiments in development economics see Duflo and Kremer (2005) and Duflo, Glennerster, and Kremer (2007).

${ }^{2}$ To analyze in further detail RCTs, see also Skoufias, Davis, and Behrman (1999), Rosenzweig and Wolpin (2000), and Deaton (2010).

${ }^{3}$ For a detailed review of Oportunidades see Viveros (2015).
} 
household income distribution and poverty indicators. Moreover, they show that an extension of the program's coverage to all moderately poor households could further improve current results. The expansion of Oportunidades could even further reduce child labor. The general equilibrium analysis suggests that such an extension would lead to a 2.7 per cent decrease in poverty. The authors also argue that if the Mexican government is able to afford the fiscal cost of extending Oportunidades and its related increase in public expenditure, mainly in education, school attendance rates could increase about 1.4 per cent whereas the poverty rate would fall by 2.7 per cent. Furthermore, the authors also find that an increase in the skills of the program's beneficiaries by enhancing their human capital through Oportunidades could increase future incomes of poor households decreasing the poverty rate by about 1.4 per cent.

Most evaluations of Oportunidades have been focused on assessing the short and medium-term impact of the program ${ }^{4}$. To fill the gap on long-term evaluations, Behrman, Parker, and Todd (2011) investigate two types of long-term impacts of Oportunidades. First, they look at the effects of short differential exposure (18-month) on long-term outcomes (after five and a half years) using difference-in-difference (DID) estimates to assess whether initial program's impacts persist or diminish over time. Second, the researchers look at the effects of a long differential exposure (four or five and a half years) on long-term outcomes. In this scenario, they apply difference-indifference matching (DIDM) estimates in order to find out whether there are increasing or diminishing returns during Oportunidades exposure. With respect to the first type of impact, the authors find that greater exposure to the program has increased schooling by 2.4 per cent for boys and 2.7 per cent for girls. Youth with 18-month exposure to the program have achieved more schooling and this differential has persisted along the five and a half year-period under study. Results suggest that Oportunidades' impact on schooling does not decrease over time. In the second type of impact, results confirm significantly larger effects on schooling with a longer exposure to the program.

To evaluate the impact of Oportunidades on schooling and labor market outcomes, Parker and Teruel (2012) carry out difference-in-difference estimators to compare young adults in selected communities receiving Oportunidades in the period 19971998 (early beneficiaries) with the results of those receiving it in 2004 or later (late beneficiaries). The main objective is to investigate whether beneficiaries in early adulthood obtain higher earnings as a result of having benefited from Oportunidades. The study's hypothesis states that the increase in school attainment will lead to increased lifetime earnings through returns to education. The authors find, on the one hand, increased effects of the program on education over time. The overall impact is in the range of 0.5 grades of additional schooling. Moreover, they find significant effects on the likelihood of attending high school by about 5 per cent. On the other hand, concerning labor market outcomes, the authors find that Oportunidades increases the share of early beneficiaries who are working compared to those late beneficiaries by about 13 per cent. The program shows, in contrast, only a few

${ }^{4}$ About the program's medium-term impact see Behrman, Parker, and Todd (2009). 
significant effects on hours worked as well as health benefits whereas no significant effect is found on labor income per hour worked. Oportunidades seems to have only limited impacts on work outcomes for beneficiaries between ages 22 and 26 . The authors argue that returns to education are not high enough to induce a significant change in earnings, probably because of low quality of education or lack of employment opportunities in rural areas.

With respect to type I and type II errors, the Inter-American Development Bank [IADB] (2012) finds that 62 per cent of the population with an income below the minimum wellbeing line does not receive Oportunidades transfers, and estimates an exclusion error of 77 per cent in urban areas and 34 per cent in rural settings. On the other hand, concerning the inclusion error, one of every five beneficiaries in urban areas and one of every four in rural settings - has an income above the wellbeing line and should not receive such transfers intended for poverty reduction.

Conditional cash transfers were conceived as a temporary program to enhance the human capital of the poor so that they could get employed, earn higher wages, and eventually reach a higher level of net disposable income that would allow them to break the intergenerational transmission of poverty. However, after eighteen years of implementation, such process has not taken place. The empirical evidence shows that

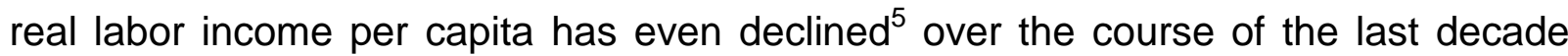
and poverty has remained high, despite the positive [marginal] impact of CCTs on education, health and nutrition of household beneficiaries.

In this context, it is necessary to re-formulate the strategies to stimulate economic growth and reduce poverty. It is rather required to implement alternative policies with a systemic approach, in which inclusive economic growth and its distributional pattern are oriented towards poverty and income inequality eradication. In this respect, this work aims, on one hand, at assessing a strategy design that would accelerate poverty reduction without jeopardizing Mexico's economic development in the regional setting of Chiapas. Pro-growth and pro-poor tax structures are also explored to finance social policy, and alternative strategies are analyzed to boost rural growth and regional development. On the other hand, given the fact that poverty would increase with the elimination of Oportunidades [Prospera] ${ }^{6}$, this study also evaluates an increase of such transfers in the educational and food components along with a redistribution to deal with exclusion and inclusion errors. To achieve these objectives, a Social Accounting Matrix (SAM) with Oportunidades broken down by component ${ }^{7}$ is built, and a CGE model in a bottom-up approach is applied to elaborate public policy recommendations for pro-poor growth and poverty reduction.

\footnotetext{
${ }^{5}$ As a matter of fact, there is a downward trend since 2005 both nationwide and in Chiapas, the poorest region (CONEVAL, 2015a). Furthermore, the purchasing power of labor income has fallen with respect to the value of a food basket because of rising commodity prices (CONEVAL, 2015b).

${ }^{6}$ The IADB (2012) estimates that poverty would increase between 17.5 per cent and 20.9 per cent at national level, and between 30.4 per cent and 40 per cent in rural areas.

7 Oportunidades [Prospera] has five components: 'alimentación', 'adultos mayores', 'educación', 'infantil vivir mejor', and 'energético', which are called in the SAM as food, elderly, education, child, and energy, respectively.
} 
Chiapas is the chosen case study to illustrate and assess an alternative strategy since it is the state with the highest levels of poverty and informal employment in Mexico, and Oportunidades covers all of the 118 municipalities. In the period 2004-2012, Chiapas GDP per capita grew on average by -0.6 per cent. Surprisingly, the unemployment rate in such region accounts for 2.4 per cent, the lowest in the whole country. In other words, nearly 98 per cent of the economically active population is employed. However, informal employment is the predominant type of occupation. In this respect, 77.3 per cent of the employed population and 64 per cent of the nonagricultural employed population have an informal employment. The economic sectors with the largest share within informal employment are agricultural, other-services, and trade with 52.3 per cent, 18.2 per cent, and 12.7 per cent, respectively. Another relevant feature in Chiapas is that the economic sectors with the largest shares in gross value-added are other-services, trade, and construction with 22.6 per cent, 20.9 per cent, and 10.2 per cent, respectively. The agricultural sector contributes only with 8.3 per cent whereas it is the one with the largest share of informal employment, which may explain to good extent the persistence of poverty. Finally, this study estimates an exclusion error of 28.5 per cent and an inclusion error of 25 per cent in this region ${ }^{8}$.

This paper is organized as follows. Chapter two introduces the theoretical framework of this research and the conceptual model about a fiscal and investment flow for poverty reduction. Chapter three describes data sources and the construction of a SAM for Chiapas. Chapter four is focused on the applied CGE model, its assumptions and macroclosures. In chapter five, a cumulative simulation and its results are presented. Chapter six discusses results and main findings while chapter seven summarizes the discussion, concludes and suggests further research.

\section{Theoretical Framework}

This study is based on the theoretical framework of pro-poor macroeconomics (UNDP, 2008). According to this approach the government shall play a relevant and indispensable role to foster inclusive economic growth and poverty reduction. In this respect, active public policies, such as fiscal and monetary policies, are important because a market-oriented strategy should not be expected to generate pro-poor growth (UNDP, 2008). Specifically, a comprehensive and progressive fiscal policy to encourage economic development and reduce poverty is required. Thus, public investment is a crucial fiscal instrument for pro-poor growth.

Also, this work assumes that the rate of economic growth is a relevant determinant of the rate of absolute poverty reduction (Ravallion, 2004). However, in order to accelerate the process of absolute poverty reduction a strong combination of growth and distribution policies is required (Bourguignon, 2004). In this respect, this study follows the theoretical approach of the 'Poverty-Growth-Inequality Triangle' (Bourguignon, 2004). This triangle implies that absolute poverty reduction is determined by the interrelation between the growth of the mean income and changes

\footnotetext{
${ }^{8}$ Both errors are estimated using the methodology introduced by Cornia and Stewart (1993).
} 
in the distribution of income. Hence, the main challenge of any development strategy relies on the mechanics of growth and distribution. Furthermore, a key issue is to generate high overall economic growth from which poor people can clearly benefit by implementing appropriate policies leading to a pro-poor distributional change (Klasen, 2009). Growth should be accompanied by a pro-poor distributional adjustment with the aim of alleviating poverty and income inequality.

Pro-poor growth takes place when the income of the poor grows more than that of the rich $^{9}$. According to Klasen (2009), pro-poor growth has seven main determinants: a strong state, an improved productivity in agriculture, improved asset base, reduced gender inequality, reduced inequality of disadvantaged groups, reduced regional inequality, and political economy. In the context of this research, reduced regional inequality plays a central role since the assessment is carried out in the regional setting of Chiapas. To achieve reduced regional inequality it is required to implement a comprehensive strategy based on infrastructure policies, targeted public investment for lagging regions, support for migration and remittances, safety nets, and pro-poor fiscal decentralization (Klasen, 2009).

Likewise, this research is also based on the approach of the revisited structural transformation and rural change introduced by Losch, Fréguin-Gresh, and White (2012). According to this theoretical framework, the diversification-income relationship is mainly characterized by an inverted $U$ pattern. As household income begins to increase households remain at risk but they start gaining some capacity to maneuver and build safety nets. When the process of income growth continues, households start diversifying their economic activities in order to expand their sources of income and reduce their vulnerability to shocks. At this point the diversification process only occurs at the household level, the so-called within-household diversification, while the region continues to be specialized in agriculture. This process leads to a stage in which households are able to build an asset and wealth base by specializing in different economic activities, either on-farm or off-farm or both, with the aim of meeting their needs and lowering their risk and vulnerability while the region becomes economically diversified, the so-called between-household diversification. This diversificationspecialization process encourages rural growth, structural transformation and rural change and leads to poverty reduction.

To bring together in a systematic fashion the theoretical approaches described above, this paper proposes a conceptual model for poverty and income inequality reduction in Mexico, shown below in figure 2.1. This conceptual model seeks to enhance a fiscal and investment flow based on three pillars: 1) pro-growth and pro-poor fiscal policy; 2) pro-poor rural growth, structural transformation, and rural change; and, 3) the formal labor market. Pro-growth and pro-poor fiscal policy is focused on tax reform, on one hand, to raise the tax revenue to finance social policy and public investment, and on

\footnotetext{
${ }^{9}$ The World Bank provides two definitions of pro-poor growth. A relative definition which states that pro-poor growth takes places when the income of the poor grows more than the income of the non-poor. On the other hand, an absolute definition states that pro-poor growth is achieved when poverty is reduced through economic growth and progressive distributional change.
} 
the other hand, to allocate more resources to poor regions such as Chiapas. Social policy may be focused on extending Oportunidades, particularly the educational and food components of the program. Public investment, in turn, may improve the provision of public goods and services such as infrastructure, health and educational services. A higher tax revenue would allow the national government to transfer more resources to lagging regions such as Chiapas. The regional government of Chiapas could implement a program of targeting investment at the municipal level aimed at (1) building new infrastructure, (2) acquiring machinery and equipment to support primarily the agricultural sector, particularly small farmers who do not have access to credit to finance investment, and (3) improving and extending the provision of public goods and services in those localities with a lack of roads, highways, bridges, water treatment and electricity plants, schools, clinics and hospitals.

Investment from national and regional governments may foster rural economic growth and structural transformation. Higher aggregate demand may stimulate labor demand, leading to a higher level of employment. If labor demand can be met by a labor supply with better skills and higher education, the labor market may contribute to poverty reduction through labor income, which would further enhance aggregate demand. By increasing the size of the formal labor market, direct and indirect tax revenue would also grow, strengthening public finances and the government capacity to further increase or, at least, sustain investment levels. Ultimately, this fiscal and investment flow would lead to a self-sustaining process of inclusive rural economic growth and development, structural transformation, and poverty reduction. 


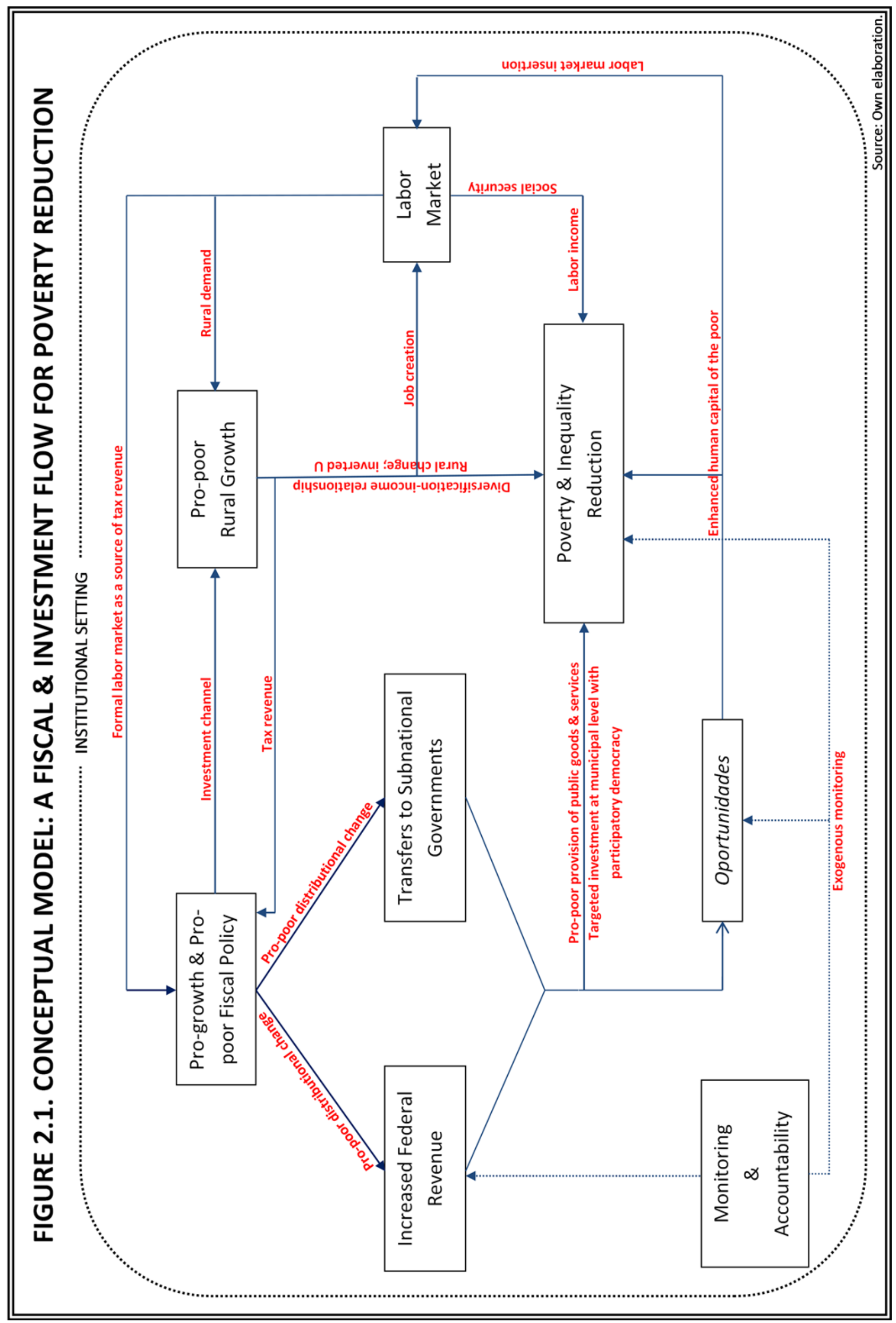




\section{Data}

A SAM is the selected method to consolidate secondary data because it is the most appropriate statistical framework and effective tool for development planning, economic analysis and forecasting (Pyatt \& Roud, 1985). The main data sources used for assembling the 2012 Chiapas SAM are the system of national accounts of the National Institute of Statistics and Geography (INEGI), the Chiapas State Committee of Statistical and Geographical Information (CEIEG), the Chiapas Ministry of Finance, the Federal Ministry of Labor and Social Welfare (STYPS), the Federal Ministry of Finance (SHCP), and the National Council for the Evaluation of Social Development Policy (CONEVAL).

The central challenge is to assemble an (i,j)-dimensional SAM representative of the Chiapas economy in 2012 with the available datasets. A SAM is a balanced square matrix that represents all income and expenditure flows between productive sectors and economic agents of an economy at a given period of time ${ }^{10}$ (Müller, Perez, \& Hubertus, 2009), and it constitutes the backbone of CGE models ${ }^{11}$. As SAMs are assembled by combining data from different sources, discrepancies may appear. The present study focuses on improving initial estimates to leave reconciliation techniques as a last resort, as suggested by Round (2003). Nonetheless, the remaining minor imbalances are dealt with by applying the methodology implemented by Lofgren, Lee Harris, and Robinson (2002) ${ }^{12}$.

All previous CGE-based research projects on Mexico use a national SAM that in some cases is disaggregated into different regions for some specific accounts, see, for instance, Coady and Lee Harris $(2001)^{13}$. In contrast, this study assembles a singleregion SAM to evaluate the revenue and expenditure flows of Chiapas' economy. A single-region SAM of the poorest state is more appropriate to analyze and find out local poverty-traps and problems in the regional economic structure hindering economic growth and poverty reduction.

The main features of the Chiapas $\mathrm{SAM}^{14}$ are that production activities are broken down in 10 sectors, according to the North American Industry Classification System (NAICS). There is one commodity per economic activity. Factors of production are disaggregated into formal and informal labor, and capital. Direct taxes are broken up into activity tax, social security contributions, household and corporate income taxes, 'tenencia' tax (ownership tax, i.e. a tax associated with the possession or use of vehicles), and regional payroll tax ('nomina'). Indirect taxes, in turn, are value-added,

\footnotetext{
10 It is based on the double entry bookkeeping in accounting, which requires that total revenue equals total expenditure in each single account included in the SAM (Breisinger, Thomas, \& Thurlow, 2010).

${ }^{11}$ A SAM can also be used in empirical multiplier analysis and input-output models. For applications on multiplier analysis see Breisinger, Thomas, and Thurlow (2010); for SAM-based models see Pyatt and Round (1985); and about CGE applications see Dervis, de Melo, and Robinson (1982).

12 Moreover, Müller, Perez, and Hubertus (2009) provide a detailed analysis of the variety of available techniques for balancing SAMs such as the RAS approach (bioproportional matrix transformation), Minimizing Quadratic Differences, Entropy approaches, and a hybrid-approach based on RAS and GCE methods as in Müller (2006).

13 They disaggregate regionally a national social accounting matrix by production and factor markets, and households by income terciles.

${ }^{14}$ For further details on the construction of the SAM see Viveros (2015). The SAM is available upon request.
} 
sales and export taxes, and import tariffs. Subsidies on production by economic activity are also included. Households are disaggregated by income quintiles. Social transfers are split in non-conditional (Procampo, universal pension, PAL-Sin Hambre $^{15}$, temporary employment program, and the regional program Amanecer ${ }^{16}$ ) and Oportunidades. The latter is also broken down into its five components: food, elderly, education, child, and energy. The introduction of conditional cash transfers in the SAM is particularly relevant because it allows assessing the impact of changes in their amount and distribution on household income, poverty reduction, income inequality, and economic growth at the regional level.

For assembling the 2012 Chiapas SAM, first, national Use and Supply matrices were estimated updating the available 2008 versions by applying the RAS method. Second, the Chiapas Use and Supply tables were then derived from the national tables using shares of the national and regional GDP-Gross value-added at basic prices by economic activity. For a detailed explanation about how the SAM was constructed see Viveros (2015).

\section{Methodology}

Most of the work done on conditional cash transfers has applied different econometric models and RTCs. In contrast, this research applies a CGE model in a bottom-up approach, i.e. based on microfoundations (see Appendix 1). It is an adaptation of the IFPRI Standard CGE (Lofgren et al., 2002). This methodology is chosen because it allows modelling the economy in a simplified manner to assess policy changes and shocks, and their implications across economic sectors and agents. In contrast, other methods, such as econometric modelling, rely on data size, are not appropriate for welfare analysis, and lack microfoundations and structural parameters, which might provide misleading results (Lucas, 1976).

One of the features of this CGE is that it is partially synthetic, that is, most parameters, such as share parameters, can be calibrated with the base-year data from the 2012 Chiapas SAM. However, some have to be taken from the literature, as is the case for behavioral elasticities ${ }^{17}$. Assumptions and macroclosures are described in Appendix 2.

The applied CGE model in this study is different from previous works in that it is focused on a state-level analysis. With a countrywide approach, in contrast, one can reach general conclusions which might not necessarily translate into viable policy alternatives for poverty reduction in the poorest regions. This is particularly true in large and heterogeneous countries such as Mexico, a country characterized by its significant regional inequality. Hence, a state-level analysis allows identifying local poverty traps and constraints for poverty reduction. Furthermore, the applied singleregion CGE allows evaluating productive activities according to NAICS, formal and informal labor, and social transfers, which are split to focus on Oportunidades. The latter is very helpful to examine the distribution of cash transfers to households by

\footnotetext{
${ }^{15}$ Based on the previous programs PAL and 70 y más.

${ }^{16}$ Amanecer is a regional social program, non-conditional transfers, to elderly for poverty reduction.

${ }^{17}$ Household consumption elasticities are taken from Viveros (2015).
} 
income quintiles, identify inconsistencies in the targeting method, and evaluate how changes in such transfers can impact the wellbeing of beneficiary households ${ }^{18}$. This study introduces the first SAM and CGE model for the regional economy of Chiapas.

\section{$5 \quad$ Simulations and results}

\subsection{Cumulative scenario one}

Governments often design economic growth and development strategies putting together a number of policies to be implemented simultaneously. It is rarely seen that a single policy is executed in isolation because decision makers tend to look for complementarities and synergies between sectors, industries, institutions, and economic agents. Hence, this section evaluates a cumulative scenario ${ }^{19}$ designed according to the political debate in Mexico about economic growth, poverty reduction, and tax structures. Likewise, it is based on the discussion led by Levy (2008), Levy, Antón, \& Hernández (2012), and Ahmad and Best (2012) on an alternative social policy for poverty reduction in Mexico and how to finance it in an efficient manner. Furthermore, as is discussed below, some of the modeled policies are also proposals suggested by this study according to the author's own economic approach and findings from the literature review.

The cumulative scenario includes Levy's proposals on the value-added tax, social security contributions, and payroll tax. It also considers a pro-poor redistribution of social (non-conditional) transfers and Oportunidades. This measure is based on the research finding that an extension of Oportunidades might further enhance its positive impact (Debowicz \& Golan, 2013). It is argued that an increase in conditional cash transfers might allow households to save a larger share of their income, which might be used to invest in farming assets or in any other productive activity that could eventually lead them to break the intergenerational transmission of poverty. Likewise, a redistribution of social transfers is based on the argument that such transfers are supposed to be exclusively allocated to the poor, as their main objective is poverty reduction. There is no reason for the rich to receive a benefit created for that purpose. It is also important to highlight that the proposed redistribution of Oportunidades and other social transfers such as Procampo, Pal-Sin Hambre, temporary employment program, and Amanecer are budget-neutral as they are only redistributed from the rich to the poor, as a way to treat both, exclusion and inclusion errors. The latter also underlines the importance of improving the targeting mechanism for transfer allocation.

Given that this study is based on the theoretical framework of pro-poor growth, the cumulative scenario also evaluates an increase in fixed investment. According to the approach on rural change and structural transformation, investment should be targeted on physical rural infrastructure for territorial development (particularly to develop the so-called missing-middle) and the provision of public goods and services

\footnotetext{
${ }^{18}$ For further details on the methodology see Viveros (2015).

${ }^{19}$ More single and cumulative scenarios for poverty reduction in Mexico are discussed in Viveros (2015).
} 
(Losch et al., 2012). In this context, a 20 per cent, 10 per cent, and 5 per cent increase in fixed investment in the agricultural, construction, and manufacturing sectors, respectively, are evaluated. This simulation is mainly focused on two sectors, agricultural and construction. On the one hand, the suggested increase in fixed investment in the agricultural sector is based on the fact that the base-level of investment is the lowest among the economic activities whereas it is the sector with the largest share of informal employment. The base-level of investment in agriculture accounts only for 0.1 per cent of GDP. It is a very low level that requires to be raised to boost economic growth and development. On the other hand, fixed investment in construction is very relevant given the economic context of Chiapas. It already accounts for 14 per cent of GDP, which makes it the economic sector with the largest shares of fixed investment. However, Chiapas is still predominantly rural, requiring higher levels of investment in construction to close the infrastructure gap. In total, fixed investment accounts for 19.2 per cent of GDP in Chiapas, below the national average of 23 per cent of GDP.

If the main goal is to restore growth and achieve poverty reduction, it is not only necessary to look at the current investment levels in key sectors of Chiapas's economy, but also to address the exclusion and inclusion errors in the allocation of Oportunidades and other non-conditional transfers. That is why this study explores both, the impact of further investment in relevant sectors for the regional economy and adjustments in the distribution of conditional cash transfers and other social transfers. Moreover, this scenario includes a 10 per cent increase in remittances. This increase in remittances is included since the American economy is slowly recovering from recession, which is expected to result in higher transfers of Mexicans in the USA to their relatives at home. The World Economic Outlook (IMF, 2015) projects the US economy to grow by 3.6 per cent in 2015 and 3.3 per cent in 2016, which may cause remittances to grow on average by 10 per cent.

Hence, the cumulative scenario is composed of:

- Redistribution of Oportunidades: a 50 per cent increase in the educational and food components for quintile one combined with the entire elimination of the program for quintile five while remaining constant for the rest of the beneficiaries

- Pro-poor redistribution of other social transfers such as Procampo, Pal-Sin Hambre, temporary employment program, and Amanecer: A) Procampo is increased by 81.4 per cent and 53 per cent for quintiles one and two, respectively, while remaining constant for quintiles three and four and eliminating it entirely for quintile five. This redistribution implies that the resources initially allocated to quintile five are reassigned by 70 per cent and 32.5 per cent to quintiles one and two, severally. B) Pal-Sin Hambre is raised by 39.4 per cent, 30 per cent, and 14.1 per cent for quintiles one, two, and three, respectively, whereas it is eliminated entirely for quintiles four and five. The latter means that the resources allocated to quintiles four and five are progressively redistributed by 60 per cent, 30 per cent, and 10 per cent, among quintiles one, two, and three, apiece. C) Temporary employment program is increased by 20.1 per cent and 57.1 per cent for quintiles 
one and two while remaining constant for quintile three. Also, it is eliminated entirely for quintiles four and five. In this case, initial transfers to quintiles four and five are reallocated by 45 per cent and 55 per cent to quintiles one and two. D) Amanecer is raised by 42.8 per cent and 27 per cent for quintiles one and two while remaining constant for quintile three. It is eliminated completely for quintiles four and five. This redistribution means that resources of quintiles four and five are reallocated by 65 per cent and 35 per cent among quintiles one and two, respectively. And, E) Universal pension is increased by 5 per cent for all households. With exception of universal pension, the structure of the redistribution of all of these transfers is budget-neutral as it only implies a reallocation of transfers from rich to poor households

- Fixed investment is increased by 20 per cent, 10 per cent, and 5 per cent in the agricultural, construction, and manufacturing sectors while remaining constant in mining and other-services. No borrowing takes place to finance investment

- Tax rate changes: A) 18.75 per cent increase of the VAT rate ${ }^{20}$; B) elimination of labor and payroll taxes; C) 10 per cent increase of the income tax rate for household quintile five; D) 10 per cent increase of corporate income tax rate; and, E) 10 per cent cut of income tax rate for household quintile two

- Remittances grow by 10 per cent

\section{$6 \quad$ Results}

Table 6.1 shows the base-value (BASE) and simulation (SIM) results with respect to GDP at market prices and GDP at factor costs along with conventional macroeconomic accounts such as private consumption, fixed investment, government consumption, exports, imports, and tax revenue. Nominal GDP grows significantly by 10.6 per cent mainly driven by fixed investment, government consumption, and stock changes, which increase by 55.6 per cent, 5.1 per cent, and 1.1 per cent, respectively. Considering that the inflation and population growth rates in Chiapas are of 4.7 per cent and 2.4 per cent in the base-year of this study, the real GDP growth rate is 6 per cent whereas the real GDP per capita growth rate is 3.5 per cent.

TABLE 6.1. GDP \& MACROECONOMIC ACCOUNTS

(Billion Mexican pesos)

\begin{tabular}{lccc} 
& BASE & SIM & $\% \Delta$ \\
\cline { 2 - 4 } ABSORPTION & 306 & 337 & 9.8 \\
PRIVATE CONSUMPTION & 191 & 186 & -2.3 \\
FIXED INVESTMENT & 57 & 89 & 55.6 \\
STOCK CHANGES & 2 & 2 & 1.1 \\
GOVERNMENT CONSUMPTION & 57 & 60 & 5.1 \\
EXPORTS & 62 & 60 & -2.9 \\
IMPORTS & -90 & -88 & -1.3 \\
GDP (AT MARKET PRICES) & 279 & 309 & 10.6 \\
NET INDIRECT TAX REVENUE & 7 & 9 & 33.4 \\
GDP (AT FACTOR COSTS) & 272 & 299 & 10.0 \\
REGIONAL TAX REVENUE & 1 & 0 & -76.7
\end{tabular}

\footnotetext{
${ }^{20}$ It is equivalent to raising the VAT rate from 16 per cent to 19 per cent.
} 


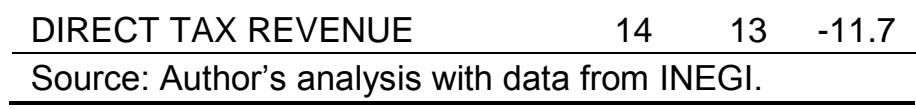

In contrast, private consumption falls on average by 2.3 per cent as a result of declining household consumption expenditure of quintiles four and five because of a lower level of disposable income for consumption. From the revenue approach, nominal GDP at factor costs grows by 10 per cent, mainly boosted by an expansion in construction, agriculture, and health-services in which factor income per unit of activity (value-added price) goes up by 88 per cent, 7.3 per cent, and 5 per cent, respectively. Real GDP at factor costs grows by 5.3 per cent while real GDP (at factor cost) per capita increases by 2.9 per cent. The indirect tax revenue, in turn, increases from $\$ 7$ to $\$ 9$ billion Mexican pesos, equivalent to 33.4 per cent. As a share of GDP at market prices, it rises from 2.5 per cent to 3.1 per cent.

On the other hand, the direct tax revenue falls from $\$ 14$ to $\$ 13$ billion Mexican pesos. As expected, the regional tax revenue declines substantially by 76.7 per cent because the payroll tax is cut out. The revenue gap created by the elimination of the payroll tax at the regional level might be compensated with federal transfers from the increased VAT-driven tax revenue. Despite the fact that the regional tax revenue drops, the elimination of the payroll tax has a positive impact on labor and household income, as will be shown below. Finally, absorption, that is, the sum of all domestically-produced goods consumed internally and all imports, grows by 9.8 per cent.

With respect to changes in labor demand, table 6.2 shows that the demanded quantity of formal labor grows in construction, health-services, and agricultural sectors by 75.4 per cent, 1 per cent, and 1 per cent, respectively, whereas the largest contraction takes place in utilities and trade by 8.5 per cent and 8 per cent, apiece. On the other hand, in the light of the assumption that labor is mobile and fully employed ${ }^{21}$, with the cumulative scenario - which includes the elimination of labor and payroll taxes informal labor declines in all sectors with the exception of construction in which it rises by 70 per cent. The wage-elasticity of labor demand in the construction sector is quite elastic. In other words, labor demand in such sector seems to be quite sensitive to changes in wages. Lastly, the largest decline in informal employment occurs in utilities and trade by 11.3 per cent and 10.9 per cent, respectively.

TABLE 6.2. DEMANDED QUANTITY OF LABOR

(Thousands of people)

\begin{tabular}{l|ccc|ccc}
\multicolumn{3}{c|}{ (Thousands of people) } \\
\cline { 2 - 7 } SECTOR & \multicolumn{3}{|c|}{ FORMAL } & \multicolumn{3}{c}{ INFORMAL } \\
\cline { 2 - 7 } & BASE & SIM & $\% \Delta$ & BASE & SIM & $\% \Delta$ \\
\hline AGRICULTURAL & 37.0 & 37.4 & 0.9 & 760.3 & 743.4 & -2.2 \\
MINING & 3.0 & 2.9 & -4.8 & 2.0 & 1.8 & -7.7 \\
UTILITIES & 2.0 & 1.8 & -8.5 & 2.0 & 1.8 & -11.3 \\
CONSTRUCTION & 16.0 & 28.1 & 75.4 & 96.0 & 163.2 & 70.0 \\
MANUFACTURING & 26.0 & 24.4 & -6.2 & 87.0 & 79.1 & -9.1 \\
TRADE & 94.0 & 86.4 & -8.0 & 184.9 & 164.8 & -10.9
\end{tabular}

\footnotetext{
${ }^{21}$ This is a plausible assumption in the context of Chiapas, given that nearly 98 per cent of the economically active population is employed. Hence, the regional economy is assumed to work at full employment.
} 


\begin{tabular}{l|ccc|ccc} 
OTHER-SERVICES & 72.0 & 68.5 & -4.8 & 263.8 & 243.5 & -7.7 \\
EDUCATION & 72.0 & 71.8 & -0.3 & 19.0 & 18.4 & -3.3 \\
HEALTH & 41.0 & 41.5 & 1.0 & 11.0 & 10.8 & -2.1 \\
PUBLIC ADM. & 61.0 & 61.2 & 0.4 & 27.0 & 26.3 & -2.7 \\
\hline \multicolumn{2}{l}{ Source: Author's analysis with data from INEGI. }
\end{tabular}

This cumulative scenario shows a positive impact on household income. Table 6.3 shows the base-value and percentage changes of factor income, total household income, and consumption expenditure. On one hand, factor income grows significantly in formal labor by 18 per cent, followed by capital income and informal labor income in which it rises by 11.2 per cent and 9.2 per cent, respectively. Total household income, on the other hand, grows in all households, however, it rises much more for the 20 per cent poorest households than for the rest. The total income of quintile one increases by 21.9 per cent while that of quintile five does so by 3.9 per cent. This result implies that, in the light of the CGE assumptions and within this cumulative scenario, pro-poor growth is achieved. If this pattern continues over time, ceteris paribus, one might expect, first, labor income to reach a larger share across all sources of household income, and, second, households to be able to escape from poverty. In contrast, any regressive effect on household consumption expenditure of the $40 \%$ poorest that is caused by a higher VAT rate is offset by the redistribution of Oportunidades and other non-conditional transfers. However, there is a negative impact on quintiles three, four, and five.

TABLE 6.3. FACTOR \& TOTAL HOUSEHOLD INCOME \& CONSUMPTION EXPENDITURE (Billion pesos)

\begin{tabular}{|c|c|c|c|c|c|c|c|c|c|c|}
\hline \multirow{3}{*}{$\begin{array}{l}\text { HOUSEHOLD } \\
\text { QUINTILES }\end{array}$} & \multirow{2}{*}{\multicolumn{2}{|c|}{$\begin{array}{l}\text { TOTAL } \\
\text { INCOME }\end{array}$}} & \multirow{2}{*}{\multicolumn{2}{|c|}{$\begin{array}{l}\text { CONSUMPTION } \\
\text { EXPENDITURE }\end{array}$}} & \multicolumn{6}{|c|}{ FACTOR INCOME } \\
\hline & & & & & \multicolumn{2}{|c|}{$\begin{array}{c}\text { FORMAL } \\
\text { LABOR }\end{array}$} & \multicolumn{2}{|c|}{$\begin{array}{c}\text { INFORMAL } \\
\text { LABOR }\end{array}$} & \multicolumn{2}{|c|}{ CAPITAL } \\
\hline & BASE & $\% \Delta$ & BASE & $\% \Delta$ & BASE & $\% \Delta$ & BASE & $\% \Delta$ & BASE & $\% \Delta$ \\
\hline HOUSEHOLD 1 & 10.6 & 21.9 & 10.6 & 14.3 & 0.7 & 17.9 & 2.4 & 9.2 & 0.2 & 11.2 \\
\hline HOUSEHOLD 2 & 16.5 & 8.5 & 16.3 & 1.9 & 2.4 & 17.9 & 3.9 & 9.2 & 0.6 & 11.2 \\
\hline HOUSEHOLD 3 & 24.9 & 6.1 & 23.1 & -0.9 & 4.0 & 17.9 & 5.6 & 9.2 & 1.3 & 11.2 \\
\hline HOUSEHOLD 4 & 43.2 & 3.3 & 37.7 & -3.8 & 6.8 & 17.9 & 9.5 & 9.2 & 2.2 & 11.2 \\
\hline HOUSEHOLD 5 & 133.5 & 3.9 & 103.1 & -4.5 & 16.1 & 17.9 & 20.7 & 9.2 & 23.2 & 11.2 \\
\hline
\end{tabular}

As a result of the positive income effect, poverty declines. Table 6.4 shows the Income Gap Ratio (IGR), the Poverty Gap Index (PGI), and the squared PGI (SPGI). First, the IGR falls from zero point forty-one to zero point twenty-eight. Second, the PGI declines notably by 31.2 per cent while the SPGI drops substantially by 52.7 per cent. In other words, the distance (gap) between the income of the poor and the poverty line gets shortened and the severity of poverty decreases. Moreover, the growth elasticity of poverty is -2.95 , that is, for every one-percent increase in GDP, poverty declines on average by 2.95 per cent.

TABLE 6.4. POVERTY REDUCTION

\begin{tabular}{l|ccc}
\hline \multirow{2}{*}{ INDICATOR } & \multicolumn{3}{|c}{ HOUSEHOLD 1 } \\
\cline { 2 - 3 } & BASE & SIM & $\% \Delta$ \\
\hline INCOME GAP RATIO & 0.41 & 0.28 &
\end{tabular}




\begin{tabular}{l|ccc} 
POVERTY GAP & 0.31 & 0.21 & $-31.2 \%$ \\
SQUARED POVERTY GAP & 0.09 & 0.04 & $-52.7 \%$ \\
\hline Source: Author's analysis with data from INEGI. \\
\hline
\end{tabular}

\section{Discussion}

Table 7.1 provides an overview of the main results. A 20 per cent, 10 per cent, and 5 per cent increase in fixed investment in agriculture, construction, and manufacturing, combined with a 50 per cent increase in the educational and food components of Oportunidades and pro-poor redistributional changes of other social transfers - such as Procampo, Pal-Sin Hambre, temporary employment program, and Amanecer boost real GDP by 6 per cent.

Moreover, informal employment falls in all economic activities, with exception of construction, and factor income increases. In this respect, formal labor income $\left(w_{f}\right)$ grows much more than capital income $(\kappa)$ and GDP growth $(g)$, shown in the table below as $w_{f}>\kappa>g$. The former rises by nearly 18 per cent while capital income and GDP growth do so by 11.2 per cent and 6 per cent, respectively. Total household income grows in all quintiles. However, it does so particularly for the poor. Pro-poor growth takes place in relative and absolute terms. In relative terms because the total income of the poorest goes up by nearly 22 per cent while that of quintile five increases by 3.9 per cent, and in absolute terms because poverty falls.

TABLE 7.1. MAIN RESULTS

\begin{tabular}{lc}
\hline GDP & $6.4 \%$ \\
GDP per capita & $4.0 \%$ \\
Informal employment & Declines in all sectors, \\
except in construction \\
Factor income & $w_{f}>\kappa>g$ \\
Pro-poor growth & Yes \\
Poverty reduction & Yes \\
Growth elasticity of poverty & $2.95 \%$ \\
Time required to exit poverty & 10 years \\
\hline Source: Author's analysis with data from INEGI. \\
\hline
\end{tabular}

Hence, a redistribution of Oportunidades and other social transfers - with the aim of targeting exclusively the poor thus eliminating the existing exclusion and inclusion errors - may also reduce income inequality and contribute to poverty reduction. Poverty reduction, measured by the Poverty Gap Index, declines by 31.2 per cent, and the growth elasticity of poverty shows that for every one-percentage change in GDP poverty goes down by 2.95 per cent. Such pro-poor redistribution of transfers may be done by improving the current targeting methodology. Moreover, raising the amount of transferred cash would allow households to save a larger share of income to invest in farming assets or other productive activities, which would lead to break the intergenerational transmission of poverty. Finally, with these policy measures the average time required to exit poverty, that is, the average time for the poorest to reach 
the poverty line, is 10 years, assuming a sustained GDP per capita growth rate of 3.5 per cent with the distributional pattern of the cumulative scenario, ceteris paribus.

Investment in the construction sector translates into investment in physical infrastructure, mainly in transport and communication, which is essential to encourage a process of structural transformation and rural change through the household-driven diversification-specialization linkage (Losch et al., 2012). To foster such process, it is required to increase farm incomes to stimulate rural demand. Hence, the government, in turn, should invest in the provision of public goods - such as bridges, highways, roads, streets, street lighting, sewer systems, power plants, water supply systems, and so forth, as well as quasi-public goods such as education and health - and in the agricultural sector, where the value-chain needs capital, to satisfy the increased rural demand that arises from the household diversification process.

Targeted investment in the construction and agricultural sectors ought to be allocated in those lagging micro-regions in Chiapas. As financial resources are scarce, prioritizing, targeting, and sequencing are important. Consequently, the first investments and interventions are to be carried out, for instance, in the 20 municipalities with the highest levels of extreme poverty identified by the National Council for the Evaluation of Social Development Policy, presented below in table 7.2. In this table, municipalities in bold mean that they are currently receiving benefits from the federal program for the development of priority areas (PDZP). The suggested strategy in this study may start focusing on those extreme-poor municipalities not covered by the PDZP while an assessment is made in the current recipients of PDZP to evaluate results and identify areas in which those municipalities may need further support to hence regional development.

Likewise, to achieve reduced regional inequality, structural transformation, rural change and poverty reduction, it is fundamental to focus on territorial development and the so-called missing-middle. From a regional development perspective, dealing with the missing-middle refers to the need to develop small and mid-size towns that may act as a bridge to link rural areas to urban centers (Losch et al., 2012). The ruralurban linkage for territorial development requires an adequate provision, in terms of quantity and quality, of public goods and services.

TABLE 7.2. MUNICIPALITIES IN EXTREME POVERTY IN CHIAPAS

(Percentage of population)

\begin{tabular}{lc|lc}
\hline Municipality & $\%$ & Municipality & $\%$ \\
\hline San Juan Cancuc & 80.5 & Tila & 69.3 \\
Chalchihuitán & 79.8 & Santiago el Pinar & 69.2 \\
Aldama & 78.8 & Chanal & 69.1 \\
Sitalá & 74.6 & Simojovel & 68.6 \\
Larráinzar & 73.0 & Maravilla Tenejapa & 68.2 \\
Chenalhó & 72.3 & Amatenango del Valle & 67.6 \\
Mitontic & 71.8 & Altamirano & 66.9 \\
Chilón & 70.6 & Sabanilla & 66.3 \\
Pantelhó & 70.3 & Tumbalá & 65.6 \\
Chamula & 69.7 & Tenejapa & 65.2 \\
\hline \multicolumn{2}{l}{ Source: Author's analysis with data from CONEVAL. }
\end{tabular}

Source: Author's analysis with data from CONEVAL. 
Lastly, as the current federal government of Enrique Peña Nieto is planning to extend the program's coverage to include people studying at the university level, it is necessary to fill in the existing gap between Oportunidades [Prospera] beneficiaries and the labor market. In other words, the program seeks to enhance the human capital of the poor so that they may be able to join the formal labor market to increase their net disposable income and break the intergenerational transmission of poverty. However, within the current structure, there is no follow-up of the labor trajectories of beneficiaries, neither any linkage between them and the labor market. There is no certainty that they will find a job in the formal sector, which is the only alternative to achieve a higher level of income and obtain social security benefits. A linkage between beneficiaries and the formal labor market is advisable to be built by implementing active labor market policies ${ }^{22}$ with the aim of increasing the likelihood of Oportunidades youth to get a job in the formal labor market. On the other hand, Oportunidades workers, i.e. parents who are beneficiaries of the program, require onthe-job training with the aim of acquiring new and improving skills so that they can increase their productivity, labor wage, and net disposable income (Levy, 2007).

\section{Conclusion}

Oportunidades was conceived as a temporary program to enhance the human capital of the poor with the aim of increasing their probability of finding a job in the formal economy, which would allow them to earn higher wages and raise total household income in order to break the intergenerational transmission of poverty. Conditional cash transfers can have a positive impact on health, nutrition and education of beneficiary household members along with positive spillover effects. However, given the current structure of the ongoing social policy and the lack of a regional development strategy and federal-local complementary policies, they are a necessary but insufficient tool for poverty reduction in the absence of sustained pro-poor economic growth and formal job creation. In this context, this paper seeks to shed light on what strategy would lead to a more effective poverty reduction without jeopardizing Mexico's economic development.

In the framework of a general-equilibrium assessment, this work shows that a policy set composed of a 20 per cent, 10 per cent, and 5 per cent increase in fixed investment in agriculture, construction, and manufacturing, an 18.75 per cent increase in the VAT rate, the elimination of labor and payroll taxes, a 10 per cent increase in the corporate income tax rate, a 10 per cent cut in the household income tax rate for quintile two, a 50 per cent increase in the educational and food components of Oportunidades for quintile one along with the elimination of the inclusion error, and pro-poor distributional changes in a budget-neutral fashion in Procampo, Pal-Sin Hambre, temporary employment program, and the regional program Amanecer, may

\footnotetext{
${ }^{22}$ For instance, an apprenticeship system so that Oportunidades youth can do a fixed-term apprenticeship with a contract and an agreed wage in a formal enterprise. Such a system might be co-financed by employers and the national and regional governments. For further information on the relationship between apprenticeships and enhanced job opportunities in the formal labor market see Picchio and Staffolani (2013).
} 
enhance a self-sustaining process of inclusive economic growth, reduce informal employment, increase factor and household income, reduce poverty, and induce a process of structural transformation and rural change.

Furthermore, the household targeting system for the allocation of transfers that are intended for poverty reduction should be improved while investments in the suggested economic sectors are executed and the diversification-specialization process takes off. It is also relevant to ensure that Oportunidades and other social programs such as Procampo, Pal-Sin Hambre, temporary employment program, and Amanecer, reach exclusively the poor.

This paper also shows that raising the VAT rate by 18.75 per cent would increase the net indirect tax revenue by 33.4 per cent, in the regional setting of Chiapas. Any regressive impact on consumption expenditure of the $40 \%$ poorest households may be offset by a pro-poor redistribution of Oportunidades and other non-conditional social transfers. However, it would harm household consumption expenditure of quintiles three, four, and five. Likewise, the elimination of social security contributions and the regional payroll tax would increase factor and household income, even though the elimination of the payroll tax would have a negative impact on the tax revenue of the regional government. Such an effect could be offset through federal transfers or grants using the additional federal tax revenue boosted by a higher VAT rate.

Moreover, in the context of the current international debate on income inequality stimulated by Thomas Piketty's book Capital in the Twenty-First Century, this study also shows that, with the economic strategy described above, formal labor income would grow at a higher rate than capital income and GDP growth, which has significant implications within the processes of structural transformation and poverty reduction, assuming that the formal labor income growth rate can be sustained over time. If the latter condition can be met, formal labor income would strengthen the financial situation of households allowing them to save or invest a larger share of net disposable income on (1) alternative non-farm economic activities, and/or on (2) health and educational/training services for household members, which would, on one hand, enhance their human capital to obtain better jobs and higher wages in the formal labor market, and, on the other hand, would foster higher rural/urban demand, encouraging economic growth and job creation while decreasing household's dependency on social transfers and leading to poverty reduction.

However, the implementation of such a policy set requires, on one hand, the political will to put into action an inclusive agenda for growth and development, and, on the other hand, the collaboration and coordination of both federal and regional governments to implement together, economic policies and institutional changes that are within their corresponding jurisdiction.

Finally, this study is different from past CGE-based works about Mexico in the sense that it carries out a state-level assessment to find out a more effective systemic strategy for poverty reduction. It is the first CGE model for the regional economy of Chiapas, the poorest state in Mexico where Oportunidades covers all of the 118 
municipalities. With a countrywide approach, in contrast, one can reach general conclusions, which might not necessarily translate into a viable economic strategy for poverty reduction in the poorest regions. The latter is particularly true in heterogeneous countries such as Mexico, a country characterized by its profound regional inequality. Therefore, a state-level assessment, such as the present study, allows identifying regional poverty traps and constraints for poverty reduction. Likewise, the applied CGE allows evaluating economic activities, investment targeting, Oportunidades broken down by component to evaluate to what extent changes by component may impact recipients, and other non-conditional social transfers such as Procampo, Pal-Sin Hambre, universal pension, temporary employment program, and the regional program known as Amanecer. Hence, the main contribution of this study is to shed light on a politically feasible set of policies to create a fiscal and investment flow to enhance inclusive economic growth, reduce poverty, and boost a process of rural change and structural transformation to reach a higher state of economic development in the regional context of Chiapas.

Further research should focus on the dynamic version of the applied CGE model with the aim of assessing inter-temporal changes in household income to find out how long it would take for households to finally break the intergenerational transmission of poverty. In addition, future research should also explore the introduction of a utility function of the labor supply to evaluate the decision-making process of workers to join the formal sector. Finally, it might also be interesting to carry out a similar assessment at national level to find out complementary alternatives for the eradication of poverty in Mexico.

\section{References}

Ahmad, E., \& Best, M. (2012). Financing social policy in the presence of informality. London School of Economics.

Armington, P. S. (1969). A theory of demand for products distinguished by place of production. Staff Papers-International Monetary Fund, 159-178.

Behrman, J. R., Parker, S. W., \& Todd, P. E. (2011). Do conditional cash transfers for schooling generate lasting benefits? A five-year follow-up of PROGRESA/Oportunidades. Journal of Human Resources, 46(1), 93-122.

Behrman, J. R., Parker, S. W., \& Todd, P. E. (2009). Medium-term impacts of the Oportunidades conditional cash transfer program on rural youth in Mexico. Poverty, Inequality and Policy in Latin America, 219-70.

Behrman, J. R., \& Todd, P. E. (1999). Randomness in the experimental samples of PROGRESA (education, health, and nutrition program). International Food Policy Research Institute, Washington, DC.

Bourguignon, F. (2004). The poverty-growth-inequality triangle. Indian Council for Research on International Economic Relations, New Delhi, 4.

Breisinger,C., Thomas, M., \& Thurlow, J. (2010). Social accounting matrices and multiplier analysis. An introduction with exercises. IFPRI. Food Security in Practice.

Burfisher, Mary E. (2011). Introduction to Computable General Equilibrium Models. United states Naval Academy, Annapolis, Maryland. Cambridge University Press. 
Coady, D. P., \& Lee Harris, R. (2001). A regional general equilibrium analysis of the welfare impact of cash transfers: An analysis of Progresa in Mexico. IFPRI, Trade and Macroeconomic Division, TMD Discussion Paper No. 76, June.

CONEVAL (2015a). Tendencias económicas y sociales de corto plazo. Resultados nacionales. Consejo Nacional de Evaluación de la Política de Desarrollo Social, Febrero. Available at:

http://www.coneval.gob.mx/Informes/ITLP/2015/4to trim 2014/ITLP\%20NACIONAL\%202014.pdf

CONEVAL (2015b). Ingreso laboral per cápita por entidad federativa. Consejo Nacional de Evaluación de la Política de Desarrollo Social, Febrero. Available at:

http://www.coneval.gob.mx/Informes/ITLP-IS/2015/ITLP IS\%20Ingreso\%20laboral\%20entidades.pdf

CONEVAL (2013). Medición de la pobreza en México y en las Entidades Federativas 2012. Consejo Nacional de Evaluación de la Política de Desarrollo Social, Julio. Available at:

http://www.coneval.gob.mx/Informes/Coordinacion/Pobreza 2012/RESUMEN EJECUTIVO MEDICIO N POBREZA 2012 Parte1.pdf

Cornia, G. A., \& Stewart, F. (1993). Two errors of targeting. Journal of International Development, 5(5), 459-496.

Deaton, A. (2010). Instruments, randomization, and learning about development. Journal of economic literature, 424-455.

Debowicz, D., \& Golan, J. (2013). The impact of Oportunidades in Mexico. International Food Policy Research Institute (IFPRI). Discussion Paper 01257, March.

Dervis, K., De Melo, J., \& Robinson, S. (1982). General equilibrium models for development policy analysis. A World Bank research publication. The World Bank.

Duflo, E., Glennerster, R., \& Kremer, M. (2007). Using randomization in development economics research: A toolkit. Handbook of development economics, 4, 3895-3962.

Duflo, E., \& Kremer, M. (2005). Use of randomization in the evaluation of development effectiveness. Evaluating Development Effectiveness, 7, 205-231.

Gertler, P. J., Martinez, S. W., \& Rubio-Codina, M. (2012). Investing cash transfers to raise long-term living standards. American Economic Journal: Applied Economics, 4(1), 164-192.

Inter-American Development Bank (IADB) (2012). Oportunidades en 2012. Evaluación y desafios. División de Protección Social y Salud. IADB, Octubre. Available at: http://issuu.com/bidsph/docs/oportunidades

International Monetary Fund [IMF] (2015). World Economic Outlook. January.

Klasen, S. (2009). Determinants of pro-poor growth. In von Braun \& Vargas \& Pandya-Lorch (2009). The poorest and hungry. Assessment, analysis, and actions. IFPRI.

Levy, S., Antón, A., \& Hernández, F. (2012). The end of informality in Mexico? Fiscal reform for universal social insurance. Inter-American Development Bank.

Levy, S. (2009). Pobreza y transición democrática en México. Fondo de Cultura Económica.

Levy, S. (2008). Good intentions, bad outcomes. Social Policy, Informality, and Economic Growth in Mexico. Brookings Institution.

Levy, S. (2007). Productividad, crecimiento y pobreza en México. ¿Qué sigue después de Oportunidades? Inter-American Development Bank. Research Department. June.

Levy, S., \& Rodríguez, E. (2005). Sin herencia de pobreza. El programa Progresa-Oportunidades de México. Inter-American Development Bank. Ed. Planeta

Ley General de Desarrollo Social (LGDS) (2004). Available at: 
http://www.diputados.gob.mx/LeyesBiblio/pdf/264.pdf

Losch, B., Fréguin-Gresh, S., \& White, E. T. (2012). Structural transformation and rural change revisited: challenges for late developing countries in a globalizing world. The World Bank.

Lofgren, H., Lee Harris, R., \& Robinson, S. (2002). A standard computable general equilibrium model in GAMS. International Food Policy Research Institute (IFPRI), Microcomputers in Policy Research 5.

Lucas, R. (1976). Econometric policy evaluation: A critique. In: Brunner, K., \& Meltzer, A. The Phillips curve and labor markets. Carnegie-Rochester Conference Series on Public Policy 1. New York: American Elsevier, pp. 19-46.

Müller, M., Pérez Domínguez, I., \& Hubertus, G. S. (2009). Construction of social accounting matrices for the EU-27 with a disaggregated agricultural sector (AgroSAM). European Commission, Institute for Prospective Technological Studies, JRC Scientific and Technical Reports, EUR 24010 EN.

Müller, M. (2006). A general equilibrium approach to modelling water and land use reforms in Uzbekistan. Dissertation University of Bonn.

Parker, S. W., \& Teruel, C. G. M. (2012). Do Conditional Cash Transfer Programs Improve Work and Earnings among its Youth Beneficiaries? Evidence after a Decade of a Mexican Cash Transfer Program.

Picchio, M., \& Staffolani, S. (2013). Does apprenticeship improve job opportunities? A regression discontinuity approach. IZA, Discussion Paper Series DP No. 7719.

Powell, A. A., \& Gruen, F. (1968). The constant elasticity of transformation production frontier and linear supply system. International Economic Review, 9(3), 315-328.

Pyatt, G., \& Round, J. (1985). Social Accounting Matrices. A basis for planning. A World Bank Symposium. The World Bank.

Ravallion, M. (2009). Economic growth and poverty reduction: Do poor countries need to worry about inequality? In: von Braun, J., Vargas Hill, R., \& Pandya-Lorch, R. (2009). The poorest and hungry. Assessments, analyses and actions. International Food Policy Research Institute. An IFPRI 2020 Book. Chapter 11.

Ravallion, M. (2004). Pro-poor growth: A primer, The World Bank. Available at: http://ideas.repec.org/p/wbk/wbrwps/3242.html [Accedido Enero 27, 2011].

Rosenzweig, M. R., \& Wolpin, K. I. (2000). Natural "natural experiments" in economics. Journal of Economic Literature, 38(4), 827-874.

Round, J. (2003). Social accounting matrices and SAM-based multiplier analysis. The impact of economic policies on poverty and income distribution: Evaluation techniques and tools, 301-24.

Skoufias, E., Davis, B., \& Behrman, J. R. (1999). Evaluación de la selección de hogares beneficiarios en el (Progresa) Programa de Educación, Salud y Alimentación. México: IFPRI.

UNDP (2008). Pro-poor macroeconomic policy: lessons from the Asia-Pacific region. UNDP.

Viveros Añorve, J. L. (2015). The opportunity cost of financing Oportunidades: a general equilibrium assessment. PhD dissertation. Center for Development Research (ZEF). University of Bonn. 


\section{Appendix 1}

\section{SETS}

$\mathrm{A}_{\mathrm{ac}}$

ACES $_{\mathrm{a}}$

$\mathrm{ALEO}_{\mathrm{a}}$

$\mathrm{C}_{\mathrm{ac}}$

$\mathrm{CD}_{\mathrm{c}}$

$\mathrm{CDN}_{\mathrm{c}}$

$\mathrm{CE}_{\mathrm{c}}$

$\mathrm{CEN}_{\mathrm{c}}$

$\mathrm{CM}_{\mathrm{C}}$

$\mathrm{CMN}_{\mathrm{c}}$

$\mathrm{CX}_{\mathrm{c}}$

$\mathrm{F}_{\mathrm{ac}}$

INS $_{\mathrm{ac}}$

INSD $_{\mathrm{i}}$

INSDNG $_{\mathrm{i}}$

$\mathrm{H}_{\mathrm{i}}$

$\mathrm{E}_{\mathrm{i}}$

$\mathrm{T}_{\mathrm{ac}}$

$\mathrm{CINV}_{\mathrm{c}}$

$\mathrm{CT}_{\mathrm{c}}$

$\mathrm{CTD}_{\mathrm{ac}}$

$\mathrm{CTE}_{\mathrm{ac}}$

CTM $_{\mathrm{ac}}$ activities

activities with CES fn. at top of technology nest

activities with Leontief fn. at top of technology nest

commodities

commodities with domestic sales of output

commodities without domestic sales of output

exported commodities

non-export commodities

imported commodities

non-imported commodities

commodities with output

factors of production

institutions

domestic institutions

domestic non-government institutions

households

enterprises

taxes

fixed investment goods

transaction service commodities

domestic transactions cost account

export transactions cost account

import transactions cost account

\section{PARAMETERS}

$\alpha_{\mathrm{a}}^{\mathrm{a}}$

$\alpha_{\mathrm{a}}^{\mathrm{ac}}$

$\alpha_{c}^{q}$

$\alpha_{c}^{t}$

$\alpha_{\mathrm{a}}^{\mathrm{va}}$ shift parameter for top level CES function

shift parameter for domestic commodity aggregation fn

shift parameter for Armington function

shift parameter for CET function

shift parameter for CES activity production function 
$\beta_{\mathrm{a}, \mathrm{c}, \mathrm{h}}^{\mathrm{h}}$ activity a for household $\mathrm{h}$

$\beta_{\mathrm{c}, \mathrm{h}}^{\mathrm{m}}$ marginal share of consumption spending on marketed commodity $c$ for household $\mathrm{h}$

cwts $_{\mathrm{c}}$

$\delta_{\mathrm{a}}^{\mathrm{a}}$

$\delta_{\mathrm{a}, \mathrm{c}}^{\mathrm{ac}}$

$\delta_{\mathrm{c}}^{\mathrm{q}}$

$\delta_{\mathrm{c}}^{\mathrm{t}}$

$\delta_{\mathrm{f}, \mathrm{a}}^{\mathrm{va}}$

dwts $_{C}$

$\gamma_{\mathrm{a}, \mathrm{c}, \mathrm{h}}^{\mathrm{h}}$ household $\mathrm{h}$

$\gamma_{\mathrm{c}, \mathrm{h}}^{\mathrm{m}}$

ica $_{c, a}$

inta $_{\mathrm{a}}$

iva $_{\mathrm{a}}$

$\operatorname{icd}_{\mathrm{c}, \mathrm{c} \prime}$

ice $_{c, c \prime}$

$\mathrm{icm}_{\mathrm{c}, \mathrm{c} \prime}$

$\operatorname{mps} 01_{\mathrm{i}}$

$\overline{\mathrm{mps}}_{\mathrm{i}}$

qdst $_{c}$

$\overline{\mathrm{qg}}_{\mathrm{c}}$

$\overline{\mathrm{qInv}}_{\mathrm{c}}$

rhoa

$\mathrm{rho}_{\mathrm{c}}^{\mathrm{ac}}$

rho $_{\mathrm{c}}^{\mathrm{q}}$

rho $_{\mathrm{c}}^{\mathrm{t}}$

rhova

shif $_{\mathrm{i}, \mathrm{f}}$

shii $_{\mathrm{i}, \mathrm{i} \prime}$

supernum $_{h}$ consumer price index weights

CES activity function share parameter

share parameter for domestic commodity aggregation function

Armington function share parameter

CET function share parameter

CES value-added function share parameter for factor $f$ in activity a domestic sales price weights

subsistence consumption of home commodity c from activity a for subsistence consumption of marketed commodity $\mathrm{c}$ for household $\mathrm{h}$ intermediate input c per unit of aggregate intermediate aggregate intermediate input coefficient aggregate value added coefficient trade input of c per unit of com cp produced \& sold dom'ly trade input of $\mathrm{c}$ per unit of com $\mathrm{cp}$ exported trade input of $\mathrm{c}$ per unit of com $\mathrm{cp}$ imported 0-1 par for potential flexing of savings rates base savings rate for domestic institution $\mathrm{i}$ quantity of stock change base-year quantity of government demand base-year quantity of private investment demand CES production function exponent domestic commodity aggregation function exponent Armington function exponent CET function exponent CES value-added function exponent share for domestic institution $i$ in income of factor $f$ share of net income of I' to $i$ (i' $\in$ INSDNG'; $i \in$ INSDNG)

LES supernumerary income 


$\begin{array}{ll}\theta_{\mathrm{a}, \mathrm{c}} & \text { yield of output c per unit of activity a } \\ \operatorname{sbpd}_{\mathrm{a}} & \text { subsidies of production } \\ \operatorname{ta}_{\mathrm{a}} & \text { tax rate for activity a } \\ \operatorname{tam}_{\mathrm{i}} & \text { rate of "tenencia" tax (regional) for domestic institution i } \\ \operatorname{te}_{\mathrm{c}} & \text { export tax rate } \\ \mathrm{tf}_{\mathrm{f}} & \text { direct tax rate for factor } \mathrm{f} \text { (social security contributions) } \\ \operatorname{tins} 01_{\mathrm{i}} & 0-1 \text { parameter with } 1 \text { for institutions with potentially flexed direct tax } \\ \operatorname{rates} & \text { exogenous direct tax rate for domestic institution i } \\ \operatorname{tins}_{\mathrm{i}} & \text { import tariff rate } \\ \operatorname{tm}_{\mathrm{c}} & \text { rate of sales tax } \\ \operatorname{tq}_{\mathrm{c}} & \text { transfer from factor } \mathrm{f} \text { to institution } \mathrm{i} \\ \operatorname{trnsfr}_{\mathrm{i}, \mathrm{f}} & \text { transfers from the rest of the world to factor } \mathrm{f} \\ \operatorname{trnsfr}_{\mathrm{f}, \mathrm{i}} & \text { rate of value-added tax for activity a } \\ \operatorname{tva}_{\mathrm{a}} & \text { rate of payroll tax (regional) } \\ \operatorname{ty}_{\mathrm{f}} & \end{array}$

\section{EXOGENOUS VARIABLES}

$\overline{\mathrm{CPI}}$

$\overline{\text { DTINS }}$ variable)

$\overline{\text { FSAV }}$

$\overline{\mathrm{GADJ}}$

$\overline{\text { IADJ }}$

$\overline{\text { MPSADJ }}$

$\overline{\mathrm{QFS}_{\mathrm{f}}}$

$\overline{\text { TINSADJ }}$

$\overline{\text { WFDIST }}_{\mathrm{f}, \mathrm{a}}$ consumer price index

change in domestic institution tax share $(=0$ for base; exogenous foreign savings (FCU)

government consumption adjustment factor investment adjustment factor savings rate scaling factor ( $=0$ for base) quantity supplied of factor direct tax scaling factor ( $=0$ for base; exogenous variable) wage distortion factor for factor $f$ in activity a

\section{ENDOGENOUS VARIABLES}

DPI

DMPS variable)

EG producer price index for domestically marketed output change in domestic institution savings rates ( $=0$ for base; exogenous government expenditures 
$\mathrm{EH}_{\mathrm{h}}$

EXR

GOVNSHR

GSAV

INVSHR

MPS $_{\mathrm{i}}$ (exogenous variable)

$\mathrm{PA}_{\mathrm{a}}$

$\mathrm{PDD}_{\mathrm{c}}$

$\mathrm{PDS}_{\mathrm{c}}$

$\mathrm{PE}_{\mathrm{c}}$

PINTA $_{a}$

$\mathrm{PM}_{\mathrm{c}}$

$\mathrm{PQ}_{\mathrm{c}}$

$\mathrm{PVA}_{\mathrm{va}}$

$\mathrm{PWE}_{\mathrm{c}}$

$\mathrm{PWM}_{\mathrm{c}}$

$\mathrm{PX}_{\mathrm{c}}$

PXAC $_{\mathrm{a}, \mathrm{c}}$

$\mathrm{QA}_{\mathrm{a}}$

$\mathrm{QD}_{\mathrm{c}}$

$\mathrm{QE}_{\mathrm{c}}$

$\mathrm{QF}_{\mathrm{f}, \mathrm{a}}$

$\mathrm{QG}_{\mathrm{c}}$

$\mathrm{QH}_{\mathrm{c}, \mathrm{h}}$

$\mathrm{QHA}_{\mathrm{c}, \mathrm{h}}$ consumption spending for household

exchange rate

government consumption share in nominal absorption

government savings

investment share in nominal absorption

marginal propensity to save for domestic nongovernment institution

activity price (unit gross revenue)

demand price for commodity produced and sold domestically

supply price for commodity produced and sold domestically

export price (domestic currency)

aggregate intermediate input price for activity a

import price (domestic currency)

composite commodity price

value-added price (factor income per unit of activity)

world export price

world import price

aggregate producer price for commodity

producer price of commodity $\mathrm{c}$ for activity a

quantity (level) of activity

quantity sold domestically of domestic output

quantity of exports

quantity required of factor $f$ from activity a

government consumption demand for commodity

quantity consumed of commodity $\mathrm{c}$ by household $\mathrm{h}$

activity a for household $\mathrm{h}$

$\mathrm{QINT}_{\mathrm{c}, \mathrm{a}}$

quantity of commodity $\mathrm{c}$ as intermediate input to activity a

QINTA $_{\mathrm{a}}$

quantity of aggregate intermediate input

$\mathrm{QINV}_{\mathrm{c}}$

quantity of investment demand for commodity

$\mathrm{QM}_{\mathrm{c}}$

quantity of imports of commodity

$\mathrm{QQ}_{\mathrm{c}}$

quantity of goods supplied to domestic market (composite supply)

$\mathrm{QT}_{\mathrm{c}}$ demanded quantity of commodity as trade input 
QVA $_{\mathrm{a}} \quad$ quantity of aggregate value-added

$\mathrm{QX}_{\mathrm{c}}$ aggregated marketed quantity of domestic output of commodity

$\mathrm{QXAC}_{\mathrm{a}, \mathrm{c}}$ quantity of marketed output of commodity c from activity a

TABS total nominal absorption

TINS $_{\mathrm{i}}$ direct tax rate for institution i (i' $\in$ INSDNG)

TRII $_{\mathrm{i}, \mathrm{i}}$ transfers from institution i' to i (both in the set INSDNG)

$\mathrm{WF}_{\mathrm{f}}$ average price of factor $f$

$\mathrm{YF}_{\mathrm{f}}$ income of factor $f$

YG government revenue

$\mathrm{YIF}_{\mathrm{i}, \mathrm{f}}$ income to domestic institution i from factor $f$

$\mathrm{YI}_{\mathrm{i}}$ income of domestic nongovernment institution

\section{EQUATIONS}

\section{Price Block}

Import price

$\mathrm{PM}_{\mathrm{c}}=\operatorname{pwm}_{\mathrm{c}}{ }^{*}\left(1+\mathrm{tm}_{\mathrm{c}}\right){ }^{*} \mathrm{EXR}+\sum_{\mathrm{c}^{\prime} \in \mathrm{CT}} \mathrm{PQ}_{\mathrm{c}}{ }^{*} \mathrm{icm}_{\mathrm{c}^{\prime} \mathrm{c}}$

\section{Export price}

$\mathrm{PE}_{\mathrm{c}}=\mathrm{pwe}_{\mathrm{c}}{ }^{*}\left(1-\mathrm{te}_{\mathrm{c}}\right){ }^{*} \mathrm{EXR}-\sum_{\mathrm{c}^{\prime} \in \mathrm{CT}} \mathrm{PQ}_{\mathrm{c}^{\prime}}{ }^{*}$ ice $_{\mathrm{c}^{\prime} \mathrm{c}}$

Demand price of domestic non-traded goods

$\mathrm{PDD}_{\mathrm{c}}=\mathrm{PDS}_{\mathrm{c}}+\sum_{\mathrm{c}^{\prime} \mathrm{CT}} \mathrm{PQ}_{\mathrm{c}^{\prime}}{ }^{*}$ icd $_{\mathrm{c}^{\prime} \mathrm{c}}$

Absorption

$\mathrm{PQ}_{\mathrm{c}}{ }^{*}\left(1-\mathrm{tq}_{\mathrm{c}}-\mathrm{sbgs}_{\mathrm{c}}\right){ }^{*} \mathrm{QQ}_{\mathrm{c}}=\mathrm{PDD}_{\mathrm{c}}{ }^{*} \mathrm{QD}_{\mathrm{c}}+\mathrm{PM}_{\mathrm{c}}{ }^{*} \mathrm{QM}_{\mathrm{c}}$

Marketed output value

$\mathrm{PX}_{\mathrm{c}}{ }^{*} \mathrm{QX}_{\mathrm{c}}=\mathrm{PDS}_{\mathrm{c}}{ }^{*} \mathrm{QD}_{\mathrm{c}}+\mathrm{PE}_{\mathrm{c}}{ }^{*} \mathrm{QE}_{\mathrm{c}}$

Activity price

$\mathrm{PA}_{\mathrm{a}}=\sum_{\mathrm{c} \in \mathrm{C}} \mathrm{PXAC}_{\mathrm{ac}}{ }^{*} \theta_{\mathrm{ac}}$

Aggregate intermediate input price

$\operatorname{PINTA}_{\mathrm{a}}=\sum_{\mathrm{c} \in \mathrm{C}} \mathrm{PQ}_{\mathrm{c}}{ }^{*}$ ica $_{\mathrm{c} \mathrm{a}}$

Activity revenue and costs

$\mathrm{PA}_{\mathrm{a}}$ * $\left(1-\mathrm{ta}_{\mathrm{a}}\right){ }^{*} \mathrm{QA}_{\mathrm{a}}=\mathrm{PVA}_{\mathrm{a}}{ }^{*} \mathrm{QVA}_{\mathrm{a}}+\mathrm{PINTA}_{\mathrm{a}}$ * $\mathrm{QINTA}_{\mathrm{a}}$

Consumer price index

$\overline{\mathrm{CPI}}=\sum_{\mathrm{c} \in \mathrm{C}} \mathrm{PXAC}_{\mathrm{a}} \mathrm{c}{ }^{*} \mathrm{PQ} \mathrm{c}$ 
Producer price index for non-traded market output

$\mathrm{DPI}=\sum_{\mathrm{c} \in \mathrm{C}} \operatorname{PDS}_{\mathrm{c}}{ }^{*} \mathrm{dwts}_{\mathrm{c}}$

\section{Production and Trade Block}

CES technology: Activity production function

$\mathrm{QA}_{\mathrm{a}}=\alpha_{\mathrm{a}}^{\mathrm{a}} *\left(\delta_{\mathrm{a}}^{\mathrm{a}} * \mathrm{QVA}_{\mathrm{a}}{ }^{-\mathrm{a}_{\mathrm{a}}^{\mathrm{a}}}+\left(1-\delta_{\mathrm{a}}^{\mathrm{a}}\right) * \mathrm{QINTA}_{\mathrm{a}}{ }^{-\rho_{\mathrm{a}}^{\mathrm{a}}}\right)^{-\frac{1}{\rho_{\mathrm{a}}^{\mathrm{a}}}}$

CES technology: Value-added function

$\mathrm{QVA}_{\mathrm{a}}=\mathrm{QINTA}_{\mathrm{a}} *\left(\frac{\mathrm{PINTA}_{\mathrm{a}}}{\mathrm{PVA}_{\mathrm{a}}} * \frac{\delta_{\mathrm{a}}^{\mathrm{a}}}{1-\delta_{\mathrm{a}}^{\mathrm{a}}}\right)^{\frac{1}{1+\rho_{\mathrm{a}}^{\mathrm{a}}}}$

Leontief technology: Demand for aggregate intermediate input

$\mathrm{QINTA}_{\mathrm{a}}=\operatorname{inta}_{\mathrm{a}}{ }^{*} \mathrm{QA}_{\mathrm{a}}$

Leontief technology: Demand for aggregate value-added

$\mathrm{QVA}_{\mathrm{a}}=\mathrm{iva}_{\mathrm{a}}{ }^{*} \mathrm{QA}_{\mathrm{a}}$

Value-added and factor demands

$\mathrm{QVA}_{\mathrm{a}}=\alpha_{\mathrm{a}}^{\mathrm{va} *}\left(\sum_{\mathrm{f} \in \mathrm{F}} \delta_{\mathrm{fa}}^{\mathrm{va}} * \mathrm{QF}_{\mathrm{fa}}{ }^{-\rho_{\mathrm{a}}^{\mathrm{va}}}\right)^{-\frac{1}{\rho_{\mathrm{a}}^{\mathrm{va}}}}$

First order condition for factor demand

$\mathrm{WF}_{\mathrm{f}} * \overline{\operatorname{WFDIST}}_{\mathrm{fa}}=$

$\mathrm{PVA}_{\mathrm{a}} *\left(1-\mathrm{tva}_{\mathrm{a}}\right) * \mathrm{QVA}_{\mathrm{a}} *\left(\sum_{\mathrm{f} \in \mathrm{F}^{\prime}} \delta_{\mathrm{fa}}^{\mathrm{va}} * \mathrm{QF}_{\mathrm{fa}}{ }^{-\rho_{\mathrm{a}}^{\mathrm{va}}}\right)^{-1} * \delta_{\mathrm{a}}^{\mathrm{va}} * \mathrm{QF}_{\mathrm{fa}}{ }^{-\rho_{\mathrm{a}}^{\mathrm{va}}-1}$

Disaggregated intermediate input demand

$\operatorname{QINT}_{\text {ca }}=$ ica $_{\text {a a }}$ " QINTA $_{\mathrm{a}}$

Commodity production and allocation

$\mathrm{QXAC}_{\mathrm{ac}}+\sum_{\mathrm{h} \in \mathrm{H}} \mathrm{QHA}_{\mathrm{ach}}=\theta_{\mathrm{ac}} * \mathrm{QA}_{\mathrm{a}}$

Output aggregation function

$\mathrm{QX}_{\mathrm{c}}=\alpha_{\mathrm{c}}^{\mathrm{ac}} *\left(\sum_{\mathrm{a} \in \mathrm{A}} \delta_{\mathrm{ac}}^{\mathrm{ac}} * \mathrm{QXAC}_{\mathrm{ac}}{ }^{-\rho_{\mathrm{c}}^{\mathrm{ac}}}\right)^{-\frac{1}{\rho_{\mathrm{c}} \mathrm{c}-1}}$

First-order condition for output aggregation function

$\mathrm{PXAC}_{\mathrm{ac}}=\mathrm{PX}_{\mathrm{c}} * \mathrm{QX}_{\mathrm{c}}\left(\sum_{\mathrm{a} \in \mathrm{A}^{\prime}} \delta_{\mathrm{ac}}^{\mathrm{ac}} * \mathrm{QXAC}_{\mathrm{ac}}^{-\rho_{\mathrm{c}}^{\mathrm{ac}}}\right)^{-1} * \delta_{\mathrm{ac}}^{\mathrm{ac}} * \mathrm{QXAC}_{\mathrm{ac}}^{-\mathrm{ac}^{\mathrm{ac}}-1}$

Output transformation (CET) function

$\mathrm{QX}_{\mathrm{c}}=\alpha_{\mathrm{c}}^{\mathrm{t}} *\left(\delta_{\mathrm{c}}^{\mathrm{t}} * \mathrm{QE}_{\mathrm{c}}^{\rho_{\mathrm{c}}^{\mathrm{t}}}+\left(1-\delta_{\mathrm{c}}^{\mathrm{t}}\right) * \mathrm{QD}_{\mathrm{c}}^{\rho_{\mathrm{c}}^{\mathrm{t}}}\right)^{\frac{1}{\rho_{\mathrm{c}}^{\mathrm{t}}}}$

Exports function 
$\mathrm{QE}_{\mathrm{c}}=\mathrm{QD}_{\mathrm{c}} *\left(\frac{\mathrm{PE}_{\mathrm{c}}}{\mathrm{PDS}_{\mathrm{c}}} * \frac{1-\delta_{\mathrm{c}}^{\mathrm{t}}}{\delta_{\mathrm{c}}^{\mathrm{t}}}\right)^{\frac{1}{\rho_{\mathrm{c}}^{\mathrm{t}}-1}}$

Output transformation for non-exported commodities

$\mathrm{QX}_{\mathrm{c}}=\mathrm{QD}_{\mathrm{c}}+\mathrm{QE}_{\mathrm{c}}$

Composite supply

$\mathrm{QQ}_{\mathrm{c}}=\alpha_{\mathrm{c}}^{\mathrm{q}} *\left(\delta_{\mathrm{c}}^{\mathrm{q}} * \mathrm{QM}_{\mathrm{c}}^{-\rho_{\mathrm{c}}^{\mathrm{q}}}+\left(1-\delta_{\mathrm{c}}^{\mathrm{q}}\right) * \mathrm{QD}_{\mathrm{c}}^{-\rho_{\mathrm{c}}^{\mathrm{q}}}\right)^{-\frac{1}{\rho_{\mathrm{c}}^{\mathrm{q}}}}$

Imports function

$\mathrm{QM}_{\mathrm{c}}=\mathrm{QD}_{\mathrm{c}} *\left(\frac{\mathrm{PDD}_{\mathrm{c}}}{\mathrm{PM}_{\mathrm{c}}} * \frac{\delta_{\mathrm{c}}^{\mathrm{q}}}{1-\delta_{\mathrm{c}}^{\mathrm{q}}}\right)^{\frac{1}{1+\rho_{\mathrm{c}}^{\mathrm{q}}}}$

Composite supply for non-imported outputs and non-produced imports

$\mathrm{QQ}_{\mathrm{c}}=\mathrm{QD}_{\mathrm{c}}+\mathrm{QM}_{\mathrm{c}}$

Demand for transaction services

$\mathrm{QT}_{\mathrm{c}}=\sum_{\mathrm{c}^{\prime} \in \mathrm{C}^{\prime}}\left(\mathrm{icm}_{\mathrm{c} \mathrm{c}^{\prime}} * \mathrm{QM}_{\mathrm{c}^{\prime}}+\mathrm{ice}_{\mathrm{c} \mathrm{c}^{\prime}} * \mathrm{QE}_{\mathrm{c}^{\prime}}+\mathrm{icd}_{\mathrm{c} \mathrm{c}^{\prime}} * \mathrm{QD}_{\mathrm{c}^{\prime}}\right)$

\section{Institution Block}

Factor income

$\mathrm{YF}_{\mathrm{f}}=\sum_{\mathrm{a} \in \mathrm{A}} \mathrm{WF}_{\mathrm{f}} * \overline{\mathrm{WFDIST}}_{\mathrm{fa}} * \mathrm{QF}_{\mathrm{fa}}+\operatorname{trnsfr} 2_{\mathrm{f} \mathrm{rowd}} * \mathrm{EXR}$

Institutional factor income

$\mathrm{YIF}_{\mathrm{if}}=\operatorname{shif}_{\mathrm{if}} *\left[\left(1-\mathrm{tf}_{\mathrm{f}}-\mathrm{ty}_{\mathrm{f}}\right) * \mathrm{YF}_{\mathrm{f}}-\operatorname{trnsfr}_{\text {rowd } \mathrm{f}} * \mathrm{EXR}\right]$

Income of domestic non-government institutions

$$
\begin{aligned}
& \mathrm{YI}_{\mathrm{i}}=\sum_{\mathrm{f} \in \mathrm{F}} \mathrm{YIF}_{\mathrm{if}}+\sum_{\mathrm{i}^{\prime} \in \text { INSDNG }} \mathrm{TRII}_{\mathrm{i} i}+\operatorname{trnsfr}_{\text {i govt }}+\operatorname{trnsfr}_{\mathrm{i} \text { food }}+\operatorname{trnsfr}_{\mathrm{i} \text { educ }}+\operatorname{trnsfr}_{\mathrm{i} \text { engy }} \\
& +\operatorname{trnsfr}_{i \text { chld }}+\operatorname{trnsfr}_{i \text { eldy }}+\operatorname{trnsfr}_{\text {p proc }}+\operatorname{trnsfr}_{i \text { unpe }}+\operatorname{trnsfr}_{\text {i pals }}+\operatorname{trnsfr}_{i \text { pemt }} \\
& +\operatorname{trnsfr}_{\text {i aman }}+\operatorname{trnsfr}_{\text {i rowd }} * \text { EXR }
\end{aligned}
$$

Intra-institutional transfers

$\mathrm{TRII}_{\mathrm{i}}{ }^{\prime}=\operatorname{shii}_{\mathrm{i}}{ }^{\prime} *\left(1-\mathrm{MPS}_{\mathrm{i}^{\prime}}\right) *\left(1-\mathrm{TINS}_{\mathrm{i}^{\prime}}\right) *\left(1-\operatorname{tam}_{\mathrm{i}^{\prime}}\right) * \mathrm{YI}_{\mathrm{i}^{\prime}}$

Household consumption expenditure

$$
\mathrm{EH}_{\mathrm{h}}=\left(1-\sum_{\mathrm{i} \in \mathrm{INSDNG}_{\mathrm{N}}} \operatorname{shii}_{\mathrm{i} \mathrm{h}}\right) *\left(1-\mathrm{MPS}_{\mathrm{h}}\right) *\left(1-\mathrm{TINS}_{\mathrm{h}}\right) *\left(1-\operatorname{tam}_{\mathrm{h}}\right) * \mathrm{YI}_{\mathrm{h}}
$$

First order condition for household consumption spending on marketed commodities

$\mathrm{PQ}_{\mathrm{c}} * \mathrm{QH}_{\mathrm{ch}}=\mathrm{PQ}_{\mathrm{c}} * \gamma_{\mathrm{ch}}^{\mathrm{m}}+\beta_{\mathrm{ch}}^{\mathrm{m}} *\left(\mathrm{EH}_{\mathrm{h}}-\sum_{\mathrm{c}^{\prime} \in \mathrm{C}} \mathrm{PQ}_{\mathrm{c}^{\prime}} * \gamma_{\mathrm{c}^{\prime} \mathrm{h}}^{\mathrm{m}}-\sum_{\mathrm{a} \in \mathrm{A}} \sum_{\mathrm{c}^{\prime} \in \mathrm{C}} \mathrm{PXAC}_{\mathrm{a} \mathrm{c}^{\prime}} * \gamma_{\mathrm{a} \mathrm{c}^{\prime} \mathrm{h}}^{\mathrm{h}}\right)$ Household consumption demand for home commodities

$\mathrm{PXAC}_{\mathrm{a} \mathrm{c}} * \mathrm{QHA}_{\mathrm{a} \mathrm{ch}}=$

$\operatorname{PXAC}_{\mathrm{a} \mathrm{c}} * \gamma_{\mathrm{a} \mathrm{ch}}^{\mathrm{h}}+\beta_{\mathrm{ac} \mathrm{h}}^{\mathrm{h}} *\left(\mathrm{EH}_{\mathrm{h}}-\sum_{\mathrm{c}^{\prime} \in \mathrm{C}} \mathrm{PQ}_{\mathrm{c}^{\prime}} * \gamma_{\mathrm{c}^{\prime} \mathrm{h}}^{\mathrm{m}}-\sum_{\mathrm{a} \in \mathrm{A}} \sum_{\mathrm{c}^{\prime} \in \mathrm{C}} \mathrm{PXAC}_{\mathrm{a} \mathrm{c}} * \gamma_{\mathrm{a} \mathrm{c}^{\prime} \mathrm{h}}^{\mathrm{h}}\right)$ Investment demand

$\mathrm{QINV}_{\mathrm{c}}=\overline{\mathrm{IADJ}} * \overline{\mathrm{qInv}}_{\mathrm{c}}$ 
Government consumption demand

$\mathrm{QG}_{\mathrm{c}}=\overline{\mathrm{GADJ}} * \overline{\mathrm{qg}}_{\mathrm{c}}$

\section{Government revenue}

$$
\begin{aligned}
& \mathrm{YG}=\sum_{\mathrm{i} \in \mathrm{INSDNG}} \mathrm{TINS}_{\mathrm{i}} * \mathrm{YI}_{\mathrm{i}} \\
& +\sum_{\mathrm{f} \in \mathrm{F}} \mathrm{tf}_{\mathrm{f}} * \mathrm{YF}_{\mathrm{f}} \\
& +\sum_{\mathrm{a} \in \mathrm{A}} \mathrm{tva}_{\mathrm{a}} * \mathrm{PVA}_{\mathrm{a}} * \mathrm{QVA}_{\mathrm{a}} \\
& +\sum_{\mathrm{a} \in \mathrm{A}} \mathrm{ta}_{\mathrm{a}} * \mathrm{PA}_{\mathrm{a}} * \mathrm{QA}_{\mathrm{a}}+\sum_{\mathrm{c} \in \mathrm{CM}} \mathrm{tm}_{\mathrm{c}} * \mathrm{pwm}_{\mathrm{c}} * \mathrm{QM}_{\mathrm{c}} * \mathrm{EXR} \\
& +\sum_{\mathrm{c} \in \mathrm{CE}} \mathrm{te}_{\mathrm{c}} * \mathrm{pwe}_{\mathrm{c}} * \mathrm{QE}_{\mathrm{c}} * \mathrm{EXR} \\
& +\sum_{\mathrm{c} \in \mathrm{C}}^{\mathrm{c} \in \mathrm{tq}_{\mathrm{c}}} * \mathrm{PQ}_{\mathrm{c}} * \mathrm{QQ}_{\mathrm{c}}+\sum_{\mathrm{c} \in \mathrm{C}} \mathrm{ty}_{\mathrm{f}} * \mathrm{YF}_{\mathrm{f}}+\sum_{\mathrm{f} \in \mathrm{F}} \mathrm{YIF}_{\mathrm{govn}}+\sum_{\mathrm{i} \in \mathrm{INSDNG}} \operatorname{tam}_{\mathrm{i}} * \mathrm{YI}_{\mathrm{i}} \\
& + \text { trnsfr }_{\text {govt govt }} * \overline{\mathrm{CPI}}+\text { trnsfr }_{\text {govt rowd }} * \text { EXR }
\end{aligned}
$$

Government expenditure 


$$
\begin{aligned}
& \mathrm{EG}=\sum_{\mathrm{c} \in \mathrm{C}} \mathrm{PQ}_{\mathrm{c}} * \mathrm{QG}_{\mathrm{c}}+\sum_{\mathrm{i} \in \mathrm{INSDNG}} \operatorname{trnsfr}_{\text {i govt }} * \overline{\mathrm{CPI}} \\
& +\sum_{i \in \text { INSDNG }} \operatorname{trnsfr}_{\text {food govt }} \\
& +\sum_{i \in \text { INSDNG }} \operatorname{trnsfr}_{\text {educ govt }} \\
& +\sum_{i \in I N S D N G} \operatorname{trnsfr}_{\text {engy govt }} \\
& +\sum_{i \in \text { INSDNG }} \text { trnsfr }_{\text {chld govt }} \\
& +\sum_{i \in I N S D N G} \text { trnsfreldy govt } \\
& +\sum_{i \in I N S D N G} \text { trnsfr }_{\text {proc govt }} \\
& +\sum_{i \in \text { INSDNG }} \operatorname{trnsfr}_{\text {unpe govt }} \\
& +\sum_{i \in I N S D N G} \operatorname{trnsfr}_{\text {pals govt }}+\sum_{i \in I_{N S D N G}} \operatorname{trnsfr}_{\text {pemt govt }}+\sum_{i \in I N S D N G} \operatorname{trnsfr}_{\text {aman govt }}+ \\
& * \overline{\mathrm{CPI}}+\sum_{\mathrm{i} \in \mathrm{INSDNG}} \operatorname{trnsfr}_{\mathrm{i} \text { govr }} * \overline{\mathrm{CPI}}+\text { trnsfr }_{\text {govt govt }} * \overline{\mathrm{CPI}}
\end{aligned}
$$

\section{System Constraint Block}

Factor market

$\sum_{\mathrm{a} \in \mathrm{A}} \mathrm{QF}_{\mathrm{fa}}=\overline{\mathrm{QFS}}_{\mathrm{f}}$

Composite commodity markets

$\mathrm{QQ}_{\mathrm{c}}=\sum_{\mathrm{a} \in \mathrm{A}} \mathrm{QINT}_{\mathrm{c} \mathrm{a}}+\sum_{\mathrm{h} \in \mathrm{H}} \mathrm{QH}_{\mathrm{ch}}+\mathrm{QG}_{\mathrm{c}}+\mathrm{QINV}_{\mathrm{c}}+\mathrm{qdst}_{\mathrm{c}}+\mathrm{QT}_{\mathrm{c}}$

Current account balance for the rest of the world

$$
\sum_{c \in C M} \operatorname{pwm}_{c} * \mathrm{QM}_{\mathrm{c}}+\sum_{\mathrm{f} \in \mathrm{F}} \operatorname{trnsfr}_{\text {rowd } \mathrm{f}}=\sum_{\mathrm{c} \in \mathrm{CE}} \mathrm{pwe}_{\mathrm{c}} * \mathrm{QE}_{\mathrm{c}}+\sum_{\mathrm{i} \in \mathrm{INSD}} \operatorname{trnsfr}_{\text {i rowd }}+\overline{\mathrm{FSAV}}
$$

Government balance

$\mathrm{YG}=\mathrm{EG}+\mathrm{GSAV}$

Direct institutional tax rates

$\operatorname{TINS}_{\mathrm{i}}=\overline{\operatorname{tIns}}_{\mathrm{i}} *\left(1+\overline{\text { TINSADJ }} *\right.$ tins $\left.01_{\mathrm{i}}\right)+\overline{\text { DTINS }} *$ tins $01_{\mathrm{i}}$

Institutional savings rates 
$\mathrm{MPS}_{\mathrm{i}}=\overline{\mathrm{mps}}_{\mathrm{i}} *\left(\overline{\operatorname{MPSADJ}} * \operatorname{mps} 01_{\mathrm{i}}\right)+\mathrm{DMPS} * \operatorname{mps} 01_{\mathrm{i}}$

Domestic non-government institutions savings

$\operatorname{INSSAV}_{\mathrm{i}}=\mathrm{MPS}_{\mathrm{i}} *\left(1-\mathrm{TINS}_{\mathrm{i}}\right) * \mathrm{YI}_{\mathrm{i}}$

Savings-Investment balance

$\sum_{\mathrm{i} \in \mathrm{INSDNG}} \mathrm{MPS}_{\mathrm{i}} *\left(1-\mathrm{TINS}_{\mathrm{i}}-\operatorname{tam}_{\mathrm{i}}\right) * \mathrm{YI}_{\mathrm{i}}+\mathrm{GSAV}+\mathrm{EXR} * \overline{\mathrm{FSAV}}$

$$
=\sum_{\mathrm{c} \in \mathrm{C}} \mathrm{PQ}_{\mathrm{c}} * \mathrm{QINV}_{\mathrm{c}}+\sum_{\mathrm{c} \in \mathrm{C}} \mathrm{PQ}_{\mathrm{c}} * \mathrm{qdst}_{\mathrm{c}}
$$

Total absorption

$$
\begin{aligned}
\text { TABS }=\sum_{\mathrm{a} \in \mathrm{A}} \sum_{\mathrm{c} \in \mathrm{C}} \mathrm{PQ}_{\mathrm{c}} * \mathrm{QH}_{\mathrm{c} \mathrm{h}} \\
+\sum_{\mathrm{a} \in \mathrm{A}} \sum_{\mathrm{c} \in \mathrm{C}} \sum_{\mathrm{h} \in \mathrm{H}} \mathrm{PXAC}_{\mathrm{a} \mathrm{c}} * \mathrm{QHA}_{\mathrm{ach}} \\
+\sum_{\mathrm{c} \in \mathrm{C}} \mathrm{PQ}_{\mathrm{c}} * \mathrm{QG}_{\mathrm{c}}+\sum_{\mathrm{c} \in \mathrm{C}} \mathrm{PQ}_{\mathrm{c}} * \mathrm{QINV}_{\mathrm{c}}+\sum_{\mathrm{c} \in \mathrm{C}} \mathrm{PQ}_{\mathrm{c}} * \mathrm{qdst}_{\mathrm{c}}
\end{aligned}
$$

Ratio of investment to absorption

INVSHR $*$ TABS $=\sum_{\mathrm{c} \in \mathrm{C}} \mathrm{PQ}_{\mathrm{c}} * \mathrm{QINV}_{\mathrm{c}}+\sum_{\mathrm{c} \in \mathrm{C}} \mathrm{PQ}_{\mathrm{c}} * \mathrm{qdst}_{\mathrm{c}}$

Ratio of government consumption to absorption

$$
\text { GOVSHR } * \text { TABS }=\sum_{c \in C} \mathrm{PQ}_{\mathrm{c}} * \mathrm{QG}_{\mathrm{c}}
$$

\section{Appendix 2: CGE assumptions, macroclosures and elasticities}

\section{Assumptions:}

- Perfect factor mobility: it implies that there are no barriers for factors to move between sectors until factor-market equilibrium is reached.

- Imperfect transformability: this refers to the producer's technological flexibility to transform production into exports or domestic sales. The producer's problem is to determine the ratio of exports and domestic sales for a given level of output that maximizes revenue on the basis of a Constant Elasticity of Transformation (CET) function.

- Imperfect substitutability: this refers to the consumer's choice and substitution between imported and domestically produced varieties of commodities in response to relative price changes at any income level on the basis of a Constant Elasticity of Substitution (CES) aggregation function (also referred to as the Armington function), (Burfisher, 2011), (Lofgren et al., 2002).

\section{Macroclosures:}

- Factors market:

- Capital is mobile and fully employed

- Formal and informal Labor is mobile and fully employed 
The latter may be appropriate in contexts where there is very low unemployment (Lofgren et al., 2002). Nearly 98 per cent of the economically active population is employed in Chiapas, hence the economy is assumed to work at full employment.

- Foreign exchange market:

- Flexible exchange rate

- Current government balance:

- Fixed direct taxes

- Flexible government savings

- Savings-Investment balance:

- Investment-driven. Fixed capital formation and the value of savings adjusts

- Numéraire:

- Consumer Price Index (CPI)

- Import and export prices are fixed

\section{Elasticities:}

- Armington elasticity: 0.8

- Constant elasticity of transformation: 1.6

- Elasticity of substitution between factors of production (at the bottom of the technology nest): 0.8

- Elasticity of substitution between aggregated factors and intermediate demand (at the top of the technology nest): 0.6

- Output aggregation elasticity for commodity c: 6

Frisch parameter: -2 